\title{
PENGARUH KOMPENSASI TERHADAP KINERJA KARYAWAN PABRIK GULA REJO AGUNG MADIUN
}

\author{
Yusuf Agung Trilaksono \\ Mahasiswa Prodi Pendidikan Ekonomi FPIPS IKIP PGRI Madiun \\ yusuf_agung777@gmail.com
}

\begin{abstract}
This study aims to determine how the compensation provided in PG Rejo Agung Madiun, want to know the performance of employees at PG Rejo Agung Baru Madiun and to determine the effect of compensation on employee performance in PG Rejo Agung Madiun.The sampling technique in this study is simple random sampling. The population in this study are all permanent employees of the PG Rejo Agung Baru Madiun numbering 104 people, while being taken as a sample of 50 people. For data analysis used a linear regression analysis, t-test, correlation and independent sample $t$ test.The results showed that the regression $\mathrm{Y}=43.534+0,276 \mathrm{X}$, constants of 43.534 , meaning if there is no variable compensation (X), then the employee's performance of 43.534 units and the coefficient of the variable compensation $(\mathrm{X})$ of 0.276 means that if the variable compensation $(\mathrm{X})$ increased by one unit, the performance of employees will increase by 0,276 units. Furthermore, from the results of independent $\mathrm{t}$ test results obtained $-\mathrm{t}_{\text {hitung }}<-\mathrm{t}_{\text {tabel }}(-2.247<-1.9845)$ or $\mathrm{Sig}_{\text {hit }}<\mathrm{Sig}$ prob $(0.027<0.05)$, meaning that compensation has different influence on the performance of employees in PG Rejo Agung Madiun.
\end{abstract}

Keywords: Compensation, Employee Performance

\begin{abstract}
Abstrak. Penelitian ini bertujuan untuk mengetahui bagaimana kompensasi yang diberikan di PG Rejo Agung Madiun, ingin mengetahui kinerja karyawan pada PG Rejo Agung Madiun dan untuk mengetahui pengaruh antara kompensasi terhadap kinerja karyawan pada PG Rejo Agung Madiun.Teknik pengambilan sampel dalam penelitian ini adalah Sampel Random Sampling. Populasi dalam penelitian ini adalah seluruh pegawai tetap PG Rejo AgungMadiun yang berjumlah 104 orang, sedangkan yang diambil sebagai sampel sebanyak 50 orang. Untuk analisa data digunakan analisa regresi linier sederhana, uji t, korelasi dan independent sampel $\mathrm{t}$ test.Hasil penelitian menunjukkan bahwa analisis regresi $\mathrm{Y}=43,534+0,276 \mathrm{X}$, konstanta sebesar 43,534, berarti apabila tidak ada variabel kompensasi (X), maka kinerja karyawan sebesar 43,534 satuan dan nilai koefisien variabel kompensasi (X) sebesar 0,276 berarti apabila variabel kompensasi (X) meningkat satu satuan maka kinerja karyawan akan meningkat sebesar 0,276 satuan. Selanjutnya dari hasil independent $\mathrm{t}$ test diperoleh hasil nilai $-\mathrm{t}_{\text {hitung }}<-\mathrm{t}_{\text {tabel }}(-2,247<-1,9845)$ atau $\mathrm{Sig}_{\text {hit }}<\operatorname{Sig}_{\text {prob }}(0,027<0,05)$, artinya kompensasi mempunyai beda pengaruh terhadap kinerja karyawan di PG Rejo Agung Madiun.
\end{abstract}

Kata Kunci: Kompensasi, Kinerja Karyawan 


\section{PENDAHULUAN}

Manusia sebagai salah satu Sumber Daya yang bersifat dinamis dan memiliki kemampuan untuk terus berkembang sehingga perlu mendapat perhatian dari pihak perusahaan. Perhatian ini diperlukan mengingat dalam menjalankan aktivitasnya, perusahaan akan selalu berhadapan dengan sumberdaya manusia yang dimilikinya. Dengan demikian pembinaan terhadap sumberdaya manusia perlu terus mendapatkan perhatian mengingat pesan sumberdaya manusia yang besar dalam suatu perusahaan.

Kompensasi merupakan salah satu fungsi yang penting dalam manajemen sumber daya manusia (MSDM). Karena kompensasi merupakan salah satu aspek yang paling sensitif di dalam hubungan kerja (Edy Sutrisno, 2009: 181)

Melalui kerja manusia berharap dapat memperoleh imbalan atau kompensasi yang akan digunakan untuk memenuhi kebutuhannya tersebut. Kebutuhan manusia bermacam-macam dan berbeda-beda antara yang satu dengan yang lainnya. Hal ini dapat diartikan bila kebutuhan karyawan dalam suatu perusahaan dapat dipenuhi, mereka akan mendukung dan patuh menjalankan perintah pimpinannya.

Kinerja merupakan perwujudan kerja yang dilakukan oleh karyawan yang biasanya dipakai sebagai dasar penilaian terhadap karyawan atau organisasi, sehingga perlu diupayakan untuk meningkatkan kinerja. Dan faktor-faktor yang mempengaruhi kompensasi ini diantaranya ialah: Kinerja, kualitas kinerja, dan motivasi kerja.

Surya Dharma (2005: 45) Manajemen kinerja didasarkan kepada batasan yang disepakati tentang kontribusi yang diharapkan dari karyawan dalam pencapaian sasaran kelompok, departemen, fungsi dan organisasi secara keseluruhan. Dalam hal inimaka dalam hal ini dapat dikatakan bahwa kinerja itu mempengaruhi kompensasi yang nantinya akan diberikan pada karyawan Pabrik Gula Rejo Agung Madiun.

Pabrik Gula Rejo Agung menggunakan sistem kontrak pada karyawan pada saat diadakannya musim giling, hal ini juga dapat secara dinamis menguntungkan perusahaan karena perusahaan tidak perlu memberikan pesangon saat pegawai kontrak tersebut dirumahkan, bila musim giling kembali datang maka pegawai tersebut akan dipanggil kembali guna untuk bekerja kembali untuk perusahaan.

Pabrik Gula Rejo Agung menghasilkan gula yang berkualitas tinggi, sehingga hal itu dibutuhkan kinerja yang baik supaya kualitas yang dihasilkan semakin baik. Hal ini juga tak terlepas dari kompensasi yang diberikan pada karyawan, yang berupa gaji atau bonus saat masa penggilingan. Disini akan diteliti bagaimana pembagian kompensasi yang sesuai dengan kinerja karyawan tersebut, sehingga peneliti tertarik mengambil judul penelitian sebagai 
berikut "Pengaruh Kompensasi terhadap Kinerja Karyawan PG Rejo Agung Madiun".

Berdasarkan latar belakang masalah dapat dirumuskan permasalahan sebagai berikut: pertama, Bagaimanakompensasi yang diberikan pada Karyawan PG Rejo Agung Madiun?, kedua, Bagaimana kinerja karyawanpada PG Rejo Agung Madiun?, ketiga, Adakah pengaruh kompensasi terhadap kinerja karyawan PG Rejo Agung Madiun?

Tujuan yang hendak dicapai dari penelitian ini adalah sebagai berikut: pertama, Ingin mengetahui bagaimana kompensasi yang diberikan pada PG Rejo Agung Madiun, kedua, Ingin mengetahui kinerja karyawan pada PG Rejo Agung Madiun, ketiga, Adakah pengaruh antara kompensasi terhadap kinerja karyawan pada PG Rejo Agung Madiun.

Ada beberapa pendapat ahli tentang pengertian kompensasi yang dapat diberikan. Menurut Wibowo (2007: 133) Kompensasi merupakan kontraprestasi terhadap penggunaan tenaga atau jasa yang telah diberikan oleh tenaga kerja".

Menurut Singodimedjo (dalam Edy Sutrisno, 2009: 183) "kompensasi dapat diberikan dalam berbagai macam bentuk, seperti: dalam bentuk pemberian uang, pemberian material dan fasilitas, dan dalam bentuk pemberian kesempatan berkarier".

Dari uraian tersebut dapat disimpulkan bahwa kompensasi adalah sesuatu yang diberikan perusahaan kepada karyawan sebagai balas jasa mereka dan kompensasi tersebut dapat dinilai dengan uang atau tanpa uang dan mempunyai kecenderungan yang tetap.

Menurut Malayu S.P. Hasibuan (2007: 121) tujuan pemberian kompensasi (balas jasa) antara lain adalah sebagai ikatan kerja sama, kepuasan kerja, pengadaan efektif, motivasi, stabilitas karyawan, disiplin, serta pengaruh serikat buruh dan pemerintah.

1) Ikatan kerja sama

Dengan pemberian kompensasi terjalinlah ikatan kerja sama formal antara majikan dengan karyawan. Karyawan harus mengerjakan tugas-tugasnya dengan baik, sedangkan pengusaha/majikan wajib membayar kompensasi sesuai dengan perjanjian yang disepakati.

2) Kepuasan kerja

Dengan balas jasa, karyawan akan dapat memenuhi kebutuhankebutuhan fisik, status sosial, dan egoistiknya sehingga memperolah kepuasan kerja dari jabatannya.

3) Pengadaan efektif

Jika program kompensasi ditetapkan cukap besar, pengadaan karyawan yang qualified untuk perusahaan akan lebih mudah.

4) Motivasi

Jika balas jasa yang diberikan cukup besar, manajer akan mudah memotivasi bawahannya.

5) Stabilitas karyawan

Dengan program kompensasi atas prinsip adil dan layak serta eksternal konsistensi yang kompentatif maka stabilitas karyawan lebih terjamin karena turn-over relatif kecil. 
6) Disiplin

Dengan pemberian balas jasa yang cukup besar maka disiplin karyawan semakin baik. Mereka akan menyadari serta mentaati peraturan-peraturan yang berlaku.

7) Pengaruh serikat buruh Dengan program kompensasi yang baik pengaruh serikat buruh dapat dihindarkan dan karyawan akan berkonsentrasi pada pekerjaannya.

8) Pengaruh pemerintah

Jika program kompensasi sesuai dengan undang-undang perburuhan yang berlaku (seperti batas upah minimum) maka intervensi pemerintah dapat dihindarkan.

Indikator untuk kompensasi menurut Veithzal Rivai (2008:360) meliputi: gaji, upah, insentif, Kompensasi Tidak Langsung (Fringe Benefit) yang meliputi fasilitasfasilitas, seperti: asuransi-asuransi, tunjangan-tunjangan, uang pensiun, dan lain-lain.

a) Gaji

Gaji adalah balas jasa dalam bentuk uang yang diterima karyawan sebagai konsekuensi dari kedudukannya sebagai seorang karyawan yang memberikan sumbangan tenaga dan pikiran dalam mencapai tujuan perusahaan.Atau, dapat dikatakan sebagai bayaran tetap yang diterima seseorang dari keanggotaannya dalam sebuah perusahaan.

b) Upah

Upah merupakan imbalan dinansial langsung yang dibayarkan kepada karyawan berdasarkan jam kerja, jumlah barang yang dihasilkan atau banyaknya pelayanan yang diberikan. Tidak seperti gaji jumlahnya relatif tetap, besarnya upah dapat berubah-ubah tergantung pada keluaran yang dihasilkan.

c) Insentif

Insentif merupakan imbalan langsung yang dibayarkan kepada karyawan karena kinerjanya melebihi standar yang ditentukan. Insentif merupakan bentuk lain dari upah langsung diluar upah dan gaji yang merupakan kompensasi tetap, yang biasa disebut kompensasi berdasarkan kinerja (pay for performance plan).

d) Kompensasi Tidak Langsung (Fringe Benefit)

Fringe Benefit merupakan kompensasi tambahan yang diberikan berdasarkan kebijakan perusahaan terhadap semua karyawan sebagai upaya meningkatkan kesejahteraan para karyawan. Contohnya, berupa fasilitas-fasilitas, seperti: asuransiasuransi, tunjangan-tunjangan, uang pensiun, dan lain-lain.

Menurut Dharma (2010:25) "Manajeman kinerja adalah suatu cara untuk mendapatkan hasil yang lebih baik bagi organisasi, kelompok dan individu dengan memahami dan mengelola kinerja sesuai dengan target yang telah direncanakan, standard dan persyayatan kompetensi yang telah ditentukan".

Menurut Suyadi Prawirosentono (2008:27), kinerja dapat dinilai atau diukur dengan beberapa indikator yaitu: 
a) Efektifitas

Efektifitas yaitu bila tujuan kelompok dapat dicapai dengan kebutuhan yang direncanakan.

b) Tanggung jawab

Merupakan bagian yang tak terpisahkan atau sebagai akibat kepemilikan wewenang.

c) Disiplin

Yaitu taat pada hukum dan aturan yang belaku.Disiplin karyawan adalah ketaatan karyawan yang bersangkutan dalam menghormati perjanjian kerja dengan perusahaan dimana dia bekerja.

d) Inisiatif

Berkaitan dengan daya pikir, kreatifitas dalam bentuk suatu ide yang berkaitan tujuan perusahaan.Sifat inisiatif sebaiknya mendapat perhatian atau tanggapan perusahaan dan atasan yang baik. Dengan perkataan lain inisiatif karyawan merupakan daya dorong kemajuan yang akhirnya akan mempengaruhi kinerja karyawan.

Penelitian menunjukan bahwa para karyawan atau pegawai puas dengan sistem evaluasi kinerja jika dihubungkan secara langsung dengan kompensasi atau imbalan. Kompensasi dapat berbentuk kenaikan upah atau gaji, kenaikan pangkat dan jabatan, atau penghargaan lainnya.

Hipotesisi dalam penelitian ini dapat dikemukakan sebagai berikut:

1. Ada pengaruh antara kompensasi terhadap kinerja karyawan Pabrik Gula Rejo Agung di Madiun

2. Ada hubungan antara kompensasi terhadap kinerja karyawan Pabrik Gula Rejo Agung di Madiun
3. ada beda pengaruh kompensasi terhadap kinerja karyawan Pabrik Gula Rejo Agung di Madiun

\section{METODOLOGI PENELITIAN}

Tempat penelitian ini dilakukan di PG Rejo Agung yang berlokasi di Jl. Yos Sudarso Kota Madiun. Penelitian dilaksanakan pada bulan Juni 2014 sampai dengan Agustus 2014.

Rancangan penelitian adalah strategi mengatur latar penelitian agar peneliti memperoleh data valid sesuai dengan karakteristik variabel dan tujuan penelitian (Tim IKIP PGRI MADIUN, 2013: 23).Rancangan penelitian yang digunakan dalam penelitian ini adalah penelitian deskriptif (descriptive research). "Penelitian deskriptif ditujukan untuk mendeskripsikan atau menggambarkan fenomena-fenomena yang ada, baik fenomena yang bersifat alamiah ataupun rekayasa manusia" (Nana Syaodih, 2005: 72).

Menurut Sugiyono (2010: 61), "variabel bebas merupakan variabel yang mempengaruhi atau yang menjadi sebab perubahannya atau timbulnya variabel dependen (terikat)". Dalam penelitian ini variabel bebasnya adalah kompensasi, yaitu sesuatu yang diterima oleh karyawan sebagai ganti atas kontribusi dan jasa yang diberikan oleh karyawan terhadap perusahaan.

"Variabel terikat merupakan variabel yang dipengaruhi atau yang menjadi akibat, karena adanya variabel bebas", (Sugiyono, 2010: 61).Dalam penelitian ini variabel terikatnya 
adalah kinerja karyawan, yaitu hasil kerja selama periode tertentu dibandingkan dengan berbagai kemungkinan seperti standar, target atau sasaran atau kriteria tertentu.

Metode penelitian yang akan digunakan dalam penelitian ini adalah deskriptif kuantitatif, yaitu metode penelitian yang memusatkan perhatian pada masalah-masalah atau fenomena yang bersifat aktual pada saat penelitian dilakukan, kemudian menggambarkan fakta-fakta tentang masalah yang diselidiki sebagaimana adanya diiringi dengan interprestasi yang rasional dan akurat (Nawawi, 2003:64).

Populasi pada prinsipnya adalah semua anggota kelompok manusia, binatang, peristiwa, atau benda yang tinggal bersama dalam satu tempat dan secara terencana menjadi target kesimpulan dari hasil akhir suatu penelitian (Sukardi, 2003: 53). Populasi dalam penelitian ini adalah seluruh pegawai tetap PG Rejo Agung Madiun yang berjumlah 104 orang.

"Sampel adalah sebagian dari jumlah populasi yang dipilih untuk sumber data tersebut" (Sukardi, 2003: 54). Arikunto (2002:104) mengatakan, apabila populasi kurang dari 100 orang, maka diambil seluruhnya,namun bila jumlah populasinya lebih dari 100 orang, maka sampel diambil sebesar $10 \%$ $15 \%, 20 \%$ - 25\%, atau lebih. Dalam hal ini peneliti mengambil $48 \%$ dari populasi atau 50 orang pegawai tetap PG Rejo Agung Madiun.

"Teknik pengambilan sampel yang digunakan dalaml penelitian ini adalah teknik Sampel Random Sampling, yaitu suatu teknik pengambilan sampel dimana seluruh individu yang menjadi anggota populasi memilki peluang yang sama dan bebas dipilih sebagai anggota sampel" (Nana Syaodih, 2005: 255).

Teknik pengumpulan data yang digunakan dalam penelitian ini adalah metode kuisioner (angket), yaitu teknik pengumpulan data yang dilakukan dengan cara memberi seperangkat pertanyaan atau pernyataan tertulis kepada responden untuk menjawabnya (Sugiyono, 2007:199).

Menurut Suharsimi Arikunto (2002: 136) "instrumen penelitian adalah alat atau fasilitas yang digunakan oleh peneliti dalam mengumpulkan data agar pekerjaannya lebih mudah dan hasilnya lebih baik, dalam arti lebih cermat, lengkap, dan sistematis sehingga lebih mudah diolah". Instrumen yang digunakan dalam penelitian ini adalah kuesioner. Skala pengukuran yang digunakan untuk mengukur pengaruh kompensasi terhadap kinerja karyawan adalah skala Likert. Sugiyono (2007:134-135) menyatakan, "Skala Likert digunakan untuk mengukur sikap, pendapat, dan persepsi seseorang atau sekelompok orang tentang fenomena sosial dan skala Likert yang digunakan adalah sangat setuju, setuju, kurang setuju, tidak setuju, sangat tidak setuju".

Analisis data yang digunakan dalam penelitian ini yaitu uji kualitas data yang terdiri dari uji validitas dan reliabilitas, regresi linier sederhana, uji $\mathrm{t}$, korelasi dan independen $\mathrm{t}$ test. 


\section{HASIL PENELITIAN}

\section{Validitas dan Reliabilitas Data}

Validitas

Validitas adalah sejauhmana alat pengukur itu mampu mengukur apa yang ingin diukur (Umar, 2002:176). Jika $r$ hitung $>r$ tabel dan nilai $r$ positif, maka butir atau pertanyaan itu valid. Nilai $\mathrm{t}$ tabel dengan jumlah sampel sebanyak 50 orang dan $\alpha=$ 0.05 adalah 0,2787 .

\section{Variabel X (Kompensasi)}

Berdasarkan pengujian validitas variabel $\mathrm{X}_{1}$, diketahui bahwa semua nilai $r$ hitung lebih besar dari $r$ tabel, berarti semua item pertanyaan pada variabel $\mathrm{X}_{1}$ adalah valid.

\section{Variabel Y (Kinerja Karyawan)}

Berdasarkan pengujian validitas variabel $\mathrm{Y}$, diketahui bahwa semua nilai $r$ hitung lebih besar dari $r$ tabel, berarti semua item pertanyaan pada variabel $\mathrm{Y}$ adalah valid.

Reliabilitas

Instrumen yang reliabel adalah instrumen yang bila berulang kali mengukur obyek yang sama akan menghasilkan data yang sama (Sugiyono, 2002). Suatu instrumen dikatakan memiliki reliabilitas yang baik apabila nilai Alpha Cronbach $>0,6$.

Berdasarkan pengujian reliabilitas variabel $\mathrm{X}$ dan $\mathrm{Y}$, diketahui bahwa semua nilai varians item lebih besar dari $\mathrm{r}$ tabel, berarti semua item pertanyaan pada variabel $\mathrm{X}$ dan $\mathrm{Y}$ adalah reliabel.

\section{Pengujian Hipotesis}

Regresi Linier Sederhana

Hasil dari regresi linier sederhana, didapat persamaan sebagai berikut:

$Y=43,534101+0,276412 X$

Persamaan tersebut di atas dapat dijelaskan sebagai berikut:

a. Nilai konstanta sebesar 43,534101, berarti apabila tidak ada variabel kompensasi (X), maka kinerja karyawan sebesar 43,534101 satuan.

b. Nilai koefisien variabel kompensasi (X) sebesar 0,276412 berarti apabila variabel kompensasi (X) meningkat satu satuan maka kinerja karyawan akan meningkat sebesar 0,276412 satuan.

\section{Uji Korelasi}

Hasil dari uji korelasi diketahui bahwa besarnya nilai $r_{\text {hit }}$ adalah 0,293 sedangkan $r_{\text {tab }} \quad 0,2787$ dilain pihak besarnya Sig hit adalah 0,020 sedangkan $\mathrm{Sig}_{\text {prob }} 0,05$. Hal ini berarti bahwa nilai $r_{\text {hit }} \geq r_{\text {tab }}(0,293 \geq 0,2787)$ atau $\operatorname{Sig}_{\text {hit }} \leq$ $\operatorname{Sig}_{\text {prob }}(0,020 \leq 0,05)$. Berdasarkan uji korelasi tersebut dapat disimpulkan bahwa $\mathrm{H}_{0}$ ditolak, artinya ada hubungan kompensasi dengan kinerja karyawan di PG Rejo Agung Madiun dengan arah hubungan positif.

Uji t

Hasil dari uji $\mathrm{t}$ didapatkan $\mathrm{t}$ hitung sebesar 2,1195. Nilai t tabel diperoleh dari tabel $t$ dengan signifikansi $\alpha=0,05$, dengan $\mathrm{df}$ sebesar 48 yang diperoleh dari $50-2$, sehingga diperoleh $\mathrm{t}$ tabel 2,011 sedang $t$ hitung 2,1195. Karena $t_{\text {hitung }}>$ $t_{\text {tabel, }}$ maka ada pengaruh kompensasi 
terhadap kinerja karyawan PG Rejo Agung Madiun.

Independent sample $\mathrm{t}$ test

Uji ini digunakan untuk mengetahui ada atau tidaknya perbedaan rata-rata antara dua kelompok sampel yang tidak berhubungan. Hasil uji independent sample $t$ test didapatkan thit sebesar 2,247 . Sedangkan $t$ tabel pada $\alpha 95 \%$ dan $\mathrm{n}=50$ adalah 1,9845, uji dua arah.

Dari perhitungan di atas terlihat bahwa nilai $\mathrm{t}_{\mathrm{hit}}$ adalah $-2,247<\mathrm{t}_{\mathrm{tab}}$ 1,9845 berarti Ho ditolak. Jadi dapat disimpulkan bahwa ada beda pengaruh kompensasi terhadap kinerja karyawan PG Rejo Agung Madiun.

\section{Simpulan Hasil Pengujian Hipotesis}

Berdasarkan hasil pengujian di atas dapat disimpulkan sebagai berikut:

\section{Regresi linier berganda}

Hasil dari pengujian regresi linier sederhana didapatkan persamaan $\mathrm{Y}=43,534+0,276 \mathrm{X}$. Berdasarkan persamaan tersebut dapat dijelaskan : (1) Nilai konstanta sebesar 43,534, berarti apabila tidak ada variabel kompensasi (X), maka kinerja karyawan sebesar 43,534 satuan dan (2) Nilai koefisien variabel kompensasi (X) sebesar 0,276 berarti apabila variabel kompensasi (X) meningkat satu satuan maka kinerja karyawan akan meningkat sebesar 0,276 satuan.

\section{Korelasi}

Hasil dari pengujian korelasi diperoleh besarnya $r_{\text {hit }}$ adalah 0,293 sedangkan $r_{\text {tab }}$ 0,2787, dilain pihak besarnya $\mathrm{Sig}_{\text {hit }}$ adalah 0,020 sedangkan $\mathrm{Sig}_{\text {prob }} 0,05$. Hal ini berarti bahwa nilai $r_{\text {hit }} \geq r_{\text {tab }}(0,293 \geq 0,2787)$ atau $\operatorname{Sig}_{\text {hit }} \leq$ $\mathrm{Sig}_{\text {prob }}(0,020 \leq 0,05)$. Sesuai hipotesis yang diajukan dapat diperoleh simpulan bahwa ada hubungan kompensasi dengan kinerja karyawan di PG Rejo Agung Madiun.

Uji t

Hasil dari uji t dapat diperoleh nilai $t_{\text {hitung }}$ adalah 2,1195sedangkan $\mathrm{t}_{\text {tabel }}$ sebesar 2,011, dilain pihak nilai $\mathrm{Sig}_{\text {hit }}$ adalah 0,039 sedangkan $\mathrm{Sig}_{\text {prob }}$ 0,05 . Hal ini berarti bahwa nilai $t_{\text {hitung }}$ $\geq \mathrm{t}_{\text {tabel }}(2,1195 \geq 2,011)$ atau $\mathrm{Sig}_{\text {hit }} \leq$ $\mathrm{Sig}_{\text {prob }}(0,039 \leq 0,05)$. Berdasarkan uji $\mathrm{t}$ tersebut dapat disimpulkan berarti Ho ditolak dan $\mathrm{Hi}$ diterima, artinya variabel kompensasi berpengaruh signifikan terhadap kinerja karyawan PG Rejo Agung Madiun.

Independent test

Berdasarkan hasil uji independent $\mathrm{t}$ test diketahui bahwa $\mathrm{F}$ hitung levene's test sebesar 0,089 dengan probabilitas 0,766 , karena probabilitas > 0,05 maka dapat disimpulkan bahwa kedua varian antara kompensasi dan kinerja karyawan sama. Dengan demikian analisis uji beda t-test harus menggunakan asumsi equal variances not assumed. Dari output SPSS terlihat bahwa nilai t pada equal variances not assumed adalah -2,247 dengan signifikansi 0,027, karena signifikansi $<$ 0,05 maka Ho ditolak. Jadi dapat disimpulkan bahwa ada beda pengaruh kompensasi terhadap kinerja karyawan PG Rejo Agung Madiun. 


\section{PEMBAHASAN}

Hasil dari pengujian korelasi diperoleh besarnya $r_{\text {hit }}$ adalah 0,293 sedangkan $r_{\text {tab }} 0,2787$, dilain pihak besarnya $\mathrm{Sig}_{\text {hit }}$ adalah 0,020 sedangkan $S_{\text {Sig }}$ prob 0,05. Hal tersebut dapat diartikan nilai $\mathrm{r}_{\text {hit }} \geq \mathrm{r}_{\mathrm{tab}}(0,293 \geq$ $0,2787)$ atau $\operatorname{Sig}_{\text {hit }} \leq \operatorname{Sig}_{\text {prob }}(0,020 \leq$ $0,05)$. Sesuai hipotesis yang diajukan dapat diperoleh simpulan bahwa ada hubungan kompensasi dengan kinerja karyawan di PG Rejo Agung Madiun.

Berdasarkan uji t diperoleh hasil sebagai berikut: nilai $t_{\text {hitung }}$ adalah 2,120 dan $\mathrm{t}_{\text {tabel }}$ adalah 2,011, nilai $\mathrm{Sig}_{\text {hit }}$ adalah 0,039 dan $\mathrm{Sig}_{\text {prob }}$ 0,05. Hal ini berarti bahwa nilai $t_{\text {hitung }} \geq t_{\text {tabel }}$ $(2,120 \geq 2,011)$ atau $\operatorname{Sig}_{\text {hit }} \leq \operatorname{Sig}_{\text {prob }}$ $(0,039 \leq 0,05)$. Sesuai hipotesis yang diajukan dapat diperoleh simpulan bahwa kompensasi berpengaruh signifikan terhadap kinerja karyawan PG Rejo Agung Madiun.

Sedangkan dari hasil uji independent $\mathrm{t}$ test diketahui bahwa $\mathrm{F}$ hitung levene's test sebesar 0,089 dengan probabilitas 0,766 , disebabkan probabilitas > 0,05 maka dapat disimpulkan bahwa kedua varian antara kompensasi dan kinerja karyawan sama. Dengan demikian analisis uji beda t-test harus menggunakan asumsi equal variances not assumed. Dari output SPSS terlihat bahwa nilai t pada equal variances not assumed adalah $-2,247$ dengan signifikansi 0,027, karena signifikansi $<0,05$ maka Ho ditolak. Jadi dapat disimpulkan bahwa ada beda pengaruh kompensasi terhadap kinerja karyawan PG Rejo Agung Madiun.
Jadi berdasarkan hasil penelitian di atas dapat disimpulkan bahwa hipotesis yang menyatakan kompensasi berpengaruh terhadap kinerja karyawan pada PG Rejo Agung Madiun dapat diterima.

\section{PENUTUP \\ Simpulan}

Berdasarkan hasil penelitian dapat disimpulkan sebagai berikut:

1. Pemberian kompensasi di PG Rejo Agung Madiun adalah baik. Hal ini terbukti dari hasil deskriptif variabel kompensasi dengan jumlah data sebanyak 50 responden mempunyai deskripsi data sebagai berikut: (a) jumlah skor total sebesar 2794; (b) nilai rata-rata hitung (mean) sebesar 55,88; (c) median sebesar 57,00; (d) modus sebesar 57; (e) standar deviasi sebesar 7,090; (f) nilai minimum sebesar 42, (g) nilai maximum sebesar 68. Dari analisis deskriptif di atas dapat dikatakan pemberian kompensasi di PG Rejo Agung Madiun baik, karena dari 50 responden hasil kuisioner yang diperoleh nilai rata-rata $\geq 55,88$ sebanyak 31 responden atau $62 \%$, sedangkan yang berada di bawah rata-rata 19 responden atau $38 \%$.

2. Kinerja karyawan di PG Rejo Agung Madiun adalah baik. Hal ini terbukti dari hasil deskriptif variabel kinerja karyawan dengan jumlah data sebanyak 50 mempunyai deskripsi data sebagai berikut:(a) jumlah skor total sebesar 2949; (b) nilai rata-rata hitung (mean) sebesar 58,98; (c) median 
sebesar 60,0; (d) modus sebesar 60; (e) standar deviasi sebesar 6,699; (f) nilai minimum sebesar 42; (g) nilai maximum sebesar 73. Dari analisis deskriptif di atas dapat dikatakan kierja karyawan di PG Rejo Agung Madiun baik, karena dari 50 responden hasil kuisioner yang diperoleh nilai hasil rata-rata $\geq 58,98$ sebanyak 28 responden atau 56\%, sedangkan yang berada di bawah rata-rata sebanyak 22 warga atau $44 \%$.

3. Pemberian kompensasi berpengaruh terhadap kinerja karyawan di PG Rejo Agung Madiun. Terbukti dari hasil analisis regresi yang memuat uji korelasi, uji $\mathrm{t}$, dan independen $\mathrm{t}$ test. Dari hasil uji korelasi diperoleh hasil nilai $r_{\text {hitung adalah } 0,293}$ sedangkan $r_{\text {tabel }} 0,2787$, dilain pihak besarnya Sig $_{\text {hit }}$ adalah 0,020 sedangkan $\mathrm{Sig}_{\text {prob }}$ 0,05. Hal ini berarti bahwa nilai $r_{\text {hitung }} \geq r_{\text {tabel }}$ $(0,293 \geq 0,2787)$ atau $\operatorname{Sig}_{\text {hit }} \leq \operatorname{Sig}_{\text {prob }}$ $(0,020 \leq 0,05)$, artinya kompensasi mempunyai hubungan yang positif dengan kinerja karyawan di PG Rejo Agung Madiun. Sedangkan dari hasil uji $\mathrm{t}$ diperoleh hasil nilai $\mathrm{t}_{\text {hitung }}$ adalah 2,120 sedangkan $\mathrm{t}_{\text {tabel }}$ sebesar 2,011, dilain pihak besarnya Sig $_{\text {hit }}$ adalah 0,039 sedangkan Sig $_{\text {prob }}$ 0,05. Hal ini berarti bahwa nilai $t_{\text {hitung }} \geq \mathrm{t}_{\text {tabel }}(2,120 \geq 2,011)$ atau $\operatorname{Sig}_{\text {hit }} \leq \operatorname{Sig}_{\text {prob }}(0,039 \leq 0,05)$, artinya kompensasi mempunyai pengaruh terhadap kinerja karyawan di PG Rejo Agung Madiun.

\section{Saran}

Setelah melakukan penelitian ini dan menyimpulkan hasilnya, akan diberikan beberapa saran yang bermanfaat bagi berbagai pihak, yaitu sebagai berikut:

1. Bagi Karyawan

Hendaknya karyawan bekerja dengan sungguh-sungguh agar target yang ditetapkan perusahaan dapat tercapai atau bisa terlampaui, agar kompensasi yang diberikan sesuai dengan hasil yang dicapainya. Karena itu untuk mendapatkan kompensasi yang lebih besar, mereka harus bekerja lebih giat dan semangat agar kinerjanya meningkat.

2. Bagi Perusahaan
Kompensasi
berpengaruh terhadap kinerja karyawan. Hendaknya perusahaan memberikan kompensasi sesuai dengan hasil yang dicapai karyawan sebagai penghargaan atas waktu dan tenaganya yang dicurahkan untuk perusahaan. Kompensasi yang diberikan dapat berupa kompensasi finansial maupun non finansial. Sebab berdasarkan hasil penelitian semakin besar kompensasi yang diberikan maka semakin meningkat pula kinerja karyawan.
3. Bagi Peneliti Mendatang
Penelitian ini diharapkan dapat dijadikan bahan referensi untuk penelitian dengan topik bahasan yang sama di masa yang akan datang. 


\section{DAFTAR PUSTAKA}

Cholid dan Abu Achmadi. 1999.

Metodologi Penelitian. Jakarta:

Bumi Aksara.

Cholid dan Abu Achmadi. 2003. Metodologi Penelitian. Jakarta:

Bumi Aksara.

Dessler, Gary. 2007. Manajemen Sumber Daya Manusia. Jilid I. Jakarta: Indeks.

2009. Manajemen

Sumber Daya Manusia. Jakarta: Indeks.

Dharma, Surya. 2010. Manajemen Kinerja. Edisi ketiga. Yogyakarta: Pustaka Pelajar.

Duwi Priyatno, 2010. Teknik Mudah dan Cepat Melakukan Analisis Data Penelitian dengan SPSS dan Tanya Jawab Ujian Pendadaran. Yogyakarta: Gaya Media.

Furtwengler, Dale. 2002. Penilaian Kinerja. Yogyakarta: ANDI.

Handoko,

Hani:2001http://jumadibismillahs ukses.blogspot.com/2012/12/peng aruh-kompensasi-terhadapkinerja.html.

2002. Manajemen

Personalia dan Sumberdaya Manusia. Yogyakarta: BPFE.
Hasan, Iqbal. 2004. Analisin Data Penelitian dengan Statistik. Jakarta: Bumi Aksara.

Hasibuan, Malaya S.P. 2007. Manajemen Sumber Daya Manusia. Jakarta: PT. Bumi Aksara.

Husaini dan Purnomo. 2004. Metodologi Penelitian Sosial. Jakarta: PT. Bumi Aksara.

Kurniadi, Fajar. 2012. Pengaruh Kompensasi dan Motivasi terhadap Kinerja Karyawan di Apotik Berkah. Bandung: Universitas Widyatama.

Mangkunegara, A.A. Anwar Prabu. 2010. Evaluasi Kinerja SDM. Bandung: PT. Refika Aditama.

Nawawi, Hadari. 2003. Metode

Penelitian Bidang Sosial, Yogyakarta: UGM Press.

Prawirosentono, Suyadi. 2008.

Kebijakan Kinerja Karyawan.

Yogyakarta : BPFE

Rivai, Veithzal. 2011. Manajemen Sumber Daya Manusia Untuk Perusahaan Dari Teori Ke Praktek. Jakarta: PT. Raja Grafindo Persada.

Sastrohadiwiryo, Siswanto. 2005. Manajemen Tenaga Kerja Indonesia. Jakarta: PT. Bumi Aksara. 
Sedarmayanti. 2011. Membangun dan Mengembangkan

Kepemimpinan. Bandung: PT.

Refika Aditama.

Sugiyono. 2007. Metode Penelitian

Kuantitatif Kualitatif . Bandung:

Alfabeta.

- 2010. Metode Penelitian

Kuantitatif Kualitatif \& RND.

Bandung : Alfabeta.

Suharsaputra Uhar. 2012. Metodologi Penelitian Kuantitatif, Kualitatif, dan Tindakan. Bandung: Refika aditama.

Sukardi. 2003. Metodologi Penelitian Kependidikan. Jakarta: Bumi Aksara

Sukmadinata, Nana Syaodih. 2005. Landasan Psikologi Proses Pendidikan. Bandung: PT Remaja Rosdakarya
Sukmadinata, Nana Syaodih. 2010. Metode Penelitian Pendidikan. Bandung: Remaja Rosdakarya.

Sutrisno, Edy. 2009. Manajemen Sumber Daya Manusia. Jakarta: PRENANDA MEDIA GROUP.

Tim IKIP PGRI Madiun. 2013. Pedoman Pendidikan Skripsi Edisi 2013. Madiun.

Umar, Husein. 2011. Metode Penelitian untuk Skripsi dan Tesis Bisnis. Jakarta: Rajawali Pers.

Usman, Andi Rianse, dan Abdi. 2012. Metodologi Penelitian Sosial dan Ekonomi. Bandung : Alfabeta

Wibowo. 2007. Manajemen Kinerja. Jakarta: PT. RajaGrafindo Persada. 